\title{
Geomorphology and Landslide-Prone Area in Cisolok District, Sukabumi Regency
}

\author{
Mochamad Seandy Alfarabi ${ }^{1}$, Supriatna ${ }^{2, *}$, Masita Dwi Mandini Manessa ${ }^{2}$, Andry Rustanto ${ }^{2}$, and Yoanna Ristya $^{2}$ \\ ${ }^{1}$ Bachelor of Geography, Faculty of Mathematics and Natural Science, University of Indonesia, Depok - Indonesia \\ ${ }^{2}$ Department of Geography, Faculty of Mathematics and Natural Science, University Indonesia, Depok - Indonesia
}

\begin{abstract}
Sukabumi District located in Southern West Java known as a region that has diverse natural characteristics, however, it is vulnerable to disasters, especially landslides. Moreover, this study focuses on Cisolok District because this region always occurred landslides every year due to topography aspect. The aim of this study is to analyze the influence of geomorphology to landslide-prone area in Cisolok District to reduce landslides. This study used overlay analysis for geomorphology mapping, while the Frequency Ratio (FR) method used for landslide-prone area mapping. Several physical variables used in this study such as slope, elevation, lithology, geological structure, road network, stream network, land use, soil type, rainfall, and landslide location. The result shows that the study areas have diverse geomorphology units dominated by volcanic slope with steep topography. While landslide-prone area consist of four classes : namely $17,03 \%$ low, $62,05 \%$ medium, $14,4 \%$ high, and $6,51 \%$ very high. Variety of landslide vulnerability in study area influenced by terrain form, land genesis, and geomorphic process.
\end{abstract}

Keywords: Mapping; Geomorphology; Landslide-prone Areas; Frequency Ratio

\section{Introduction}

One of the natural disasters that often occurred in Indonesia is landslides [1]. It becomes an annual disaster, especially during the rainy season. Landslides in Indonesia usually occurred in steep topography and in weathered volcanic rocks [2]. In 2017, there were 848 landslides occurred in Indonesia which resulted in 163 deaths [3].

West Java Province is one of the areas with the most landslides, precisely in Sukabumi Regency [4]. Recently there has been a major landslide, hoard a residential block in the Halimun National Park area, Cisolok District. The death was reported to reach 33 people with 31 people found and two people missing. Landslide in Cisolok triggered by high rainfall, steep slope, and unstable land [4].

This study area located in Cisolok District which has the most landslide record in Sukabumi Regency and part of Ciletuh Geopark. As one of the icons of the Geopark, landslides can certainly endanger many people and visitors who come to visit. Also, there is a program by the Central Government to developing the South Java Coast which contained in Presidential Decree [5]. Early studies on disaster needed to support the program.

The physical condition of the area and the distribution of landslide events are fundamental things that must be known for assessing vulnerability [6]. The landslide-prone area in this study obtained through quantitative techniques, namely the Frequency Ratio (FR) method. This method can provide information about the probability of distribution of landslide-prone areas based on the physical characteristics of landslides which processed with GIS technology.

Geomorphology is one approach in assessing the physical condition of a region. The geomorphology aspects and processes could be used in landslide analysis [7]. In Bengal, India, information on morphometry, geology, and flow patterns used to evaluated landslideprone areas [8]. Morphometry and morphostructure also used to identify landslides in Banjarnegara, Central Java [9]. Based on the explanation above, the purpose of this study is to analyze the influence of geomorphology to landslide-prone area in order to support disaster mitigation and future development.

\section{Materials and Methods}

\subsection{Study Area}

The study area located in Cisolok District, part of Sukabumi Regency on the northwest. Geographically, it located in $6^{0} 46^{\prime} 4,8^{\prime \prime}$ - $6^{0} 58^{\prime} 44,4$ " S dan 106 23 '24" $106^{0} 33^{\prime} 18^{\prime \prime}$ E. It has various terrain due to volcanic and tectonic processes in the past, elevation range about 0 $1.740 \mathrm{~m}$ above sea level (asl) with slope range about 0 $180 \%$. According to natural conditions, this area holds the highest frequency of landslides in the region.

* Corresponding author: supriatna@ui.ac.id 


\subsection{Materials}

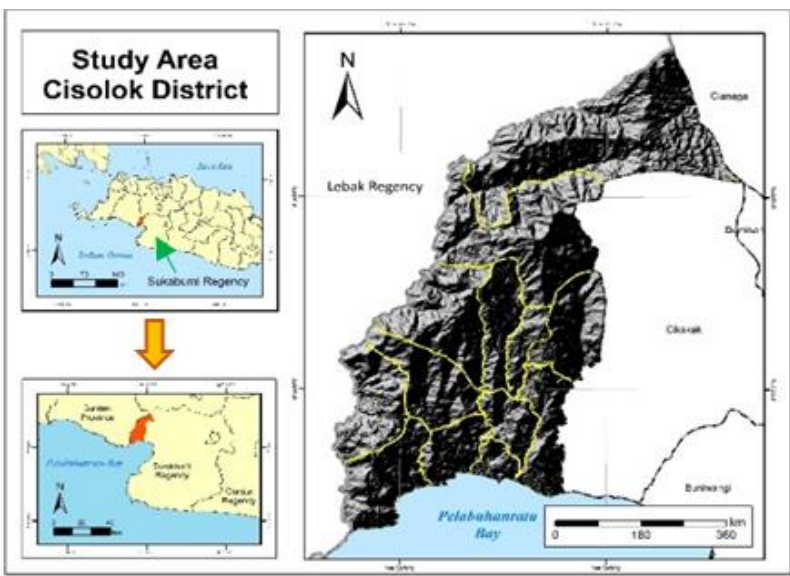

Fig. 1. The Study Area

Geomorphology and landslide mapping used physical aspects which almost similar. The Geomorphology mapping used slope, elevation, lithology, geological structure, and stream network. While landslide mapping also used slope, lithology, geological structure, stream network, added with land use, soil type, road network, rainfall, and landslide location.

The slope and elevation were extracted from the National Digital Elevation Model (DEMNAS) with a resolution of 8,5 x 8,5 m using ArcGIS 10.4. The slope angel divided into seven classes according to Van Zuidam (1985) which are $<2 \%, 2-7 \%, 7-15 \%, 15-30 \%, 30-70 \%$, $70-140 \%$, and $>140 \%$ [7].

The elevation divided into seven classes according to Van Zuidam (1985) which are $<50 \mathrm{~m}$ asl, $50-100 \mathrm{~m}$ asl, 100-200 $\mathrm{m}$ asl, 200-500 m asl, 500-1,000 m asl, 1,000$1,500 \mathrm{~m}$ asl, and $>1,500 \mathrm{~m}$ asl [7].

Lithology and geological structure derived from the geological map. The distance from fault lines for landslide mapping divided into six classes, namely $<50 \mathrm{~m}, 51-100$ $\mathrm{m}, 101-150 \mathrm{~m}, 151-200 \mathrm{~m}, 201-250 \mathrm{~m}$, and $>250 \mathrm{~m}$ [10].

Stream network, road network, and land use obtained from the Geospatial Information Agency (BIG). Stream and road network divided into six classes, namely $<50 \mathrm{~m}, 51-100 \mathrm{~m}, 101-150 \mathrm{~m}, 151-200 \mathrm{~m}, 201-250 \mathrm{~m}$, and $>250 \mathrm{~m}$ [10]. Soil types obtained from BBSLP. They classified soil type into five types namely alluvial sulfic, andosol district, cambisol district, cambisol eutric, and podsolic haplic [11].

Rainfall in the study area was quite high at about $2.829 \mathrm{~mm} /$ year. Both in flat areas and the mountains areas, relatively have homogeneous rainfall. The data were obtained from Meteorological Agency (BMKG). Rainfall classified into six classes, namely $<1.500 \mathrm{~mm}$, $1.500-2.000 \mathrm{~mm}, 2.000-2.500 \mathrm{~mm}, 2.500-3.000 \mathrm{~mm}$, $3.000-3.500 \mathrm{~mm}$, and $>3.500 \mathrm{~mm}$.

\subsection{Methods}

\subsubsection{Geomorphological Mapping}

Geomorphological mapping integrated with GIS technology and the elevation model to get landform identification. Morphology and morphogenesis are utilized to obtain geomorphology of a region [7]. The morphology obtains by overlaid the elevation and slope based on Van Zuidam (1985) classification.

Table 1. Correlation Between Slope and Height Difference

\begin{tabular}{|c|c|c|}
\hline Relief & Slope (\%) & $\begin{array}{c}\text { Height Diff } \\
(\mathbf{m})\end{array}$ \\
\hline Flat & $<2$ & $<5$ \\
\hline Wavy & $03-J u l$ & May-50 \\
\hline Wavy-Bumpy & Aug-13 & $25-75$ \\
\hline Bumpy-Hilly & $14-20$ & $75-200$ \\
\hline $\begin{array}{c}\text { Hilly- } \\
\text { Mountainous }\end{array}$ & $21-55$ & $200-500$ \\
\hline Steep Mountain & $55-140$ & $500-1.000$ \\
\hline Steep Mountain & $>140$ & $>1.000$ \\
\hline
\end{tabular}

The lithology and geological structures are applied to obtain morphogenesis of a region, and additional exogenous processes also used to complete the analysis [7]. Vertsappen (1985) and Van Zuidam (1985) specify origin landform into eight classes there are aeolian, denudational, fluvial, glacial, karst, marine, structural, and volcanic landform. Then, morphology and morphogenesis overlaid and delineated to get geomorphological units.

Table 2. Landform Classifications

\begin{tabular}{|c|c|c|}
\hline Landform & Code & Colour \\
\hline Aeolian & A & Yellow \\
\hline Denudational & D & Brown \\
\hline Fluvial & F & Green \\
\hline Glacial & G & Light Blue \\
\hline Karst & K & Orange \\
\hline Marine & M & Blue \\
\hline Structural & S & Purple \\
\hline Volcanic & V & Red \\
\hline
\end{tabular}

\subsubsection{Frequency Ratio}

The Frequency Ratio (FR) is used to derive the correlation between landslide occurrence distribution and landslide causative factors [12]. The value of the Frequency Ratio for each class of causative factors can be obtained through equations [13] : 


$$
F R=\frac{N i j / N r}{A i j / A r}
$$

where $N i j$ is the pixels of landslides each class of factor, $A i j$ is the pixels each class factor, $N r$ is the total pixels of landslides, and $A r$ is the total pixels of the study area [13]. The average value is 1 , more than 1 indicates a higher correlation to landslide occurrences and below 1 indicates a lower correlation to landslide occurrences [14]. Each causative factor that has a ratio value was calculated to get the landslide vulnerability index (LVI) with equations [15] :

$$
L V I=\sum F R
$$

The summation results were divided into several classes to determine landslide-prone areas [16].

\section{Result and Discussion}

\subsection{Geomorphology}

Morphology of study area divided into six classes there is flat area dominated by slope $<2 \%$, wavy area dominated by slope $3-7 \%$, bumpy dominated by slope $8-13 \%$, hilly dominated by slope 14-20\%, mountainous dominated by slope $21-55 \%$, and steep mountains dominated by slope $55-140 \%$. Based on morphogenesis, the study area was constructed by volcanic landform that almost covers the entire area followed by denudational, fluvial, marine, structural landform.

Table 3. Geomorphological Units of Study Area

\begin{tabular}{|c|c|c|}
\hline Geomorphology Unit & $\begin{array}{c}\text { Area } \\
\text { (Ha) }\end{array}$ & $\begin{array}{c}\text { Percentage } \\
\text { \% }\end{array}$ \\
\hline $\begin{array}{c}\text { Fluvial Volcanic-Plains } \\
\text { (V12) }\end{array}$ & 12,59 & 7,26 \\
\hline Inactive Alluvial Fans (F8) & 8,96 & 5,16 \\
\hline Volcanic Cones (V2) & 2,92 & 1,68 \\
\hline $\begin{array}{c}\text { Synclinal and Anticlinal } \\
\text { Ridges (S9) }\end{array}$ & 41,47 & 23,90 \\
\hline $\begin{array}{c}\text { Volcanic Denudational Hills } \\
\text { (V14) }\end{array}$ & 12,81 & 7,38 \\
\hline Volcanic Slopes (V3) & 94,30 & 54,35 \\
\hline Marine Terraces (M11) & 0,45 & 0,26 \\
\hline
\end{tabular}

Based on Table 3, the study area has seven types of geomorphological units; there fluvial-volcanic plains (V12), inactive alluvial fans (F8), volcanic cones (V2), synclinal and anticlinal ridges (S9), volcanic denudational hills (V14), volcanic slopes (V3), marine terraces (M11). Generally, volcanic landform majority constructed by volcanic activity in quarter period, volcanic materials like tuff and lava found and formed the andosols that have soft and loose texture. Structural landform constructed by tectonic activity between oceanic plate and continental plate that yield some joint and fault, precisely in south.

Fluvial and marine landforms mostly located in the south and the west which have flat terrain. Fluvial process especially around Bareno River, brought materials from the upside to deposit in downslope. Similar like fluvial process, a marine process also brought sands and corals to a flat area, identified by shrubs surface that contains sand layer.

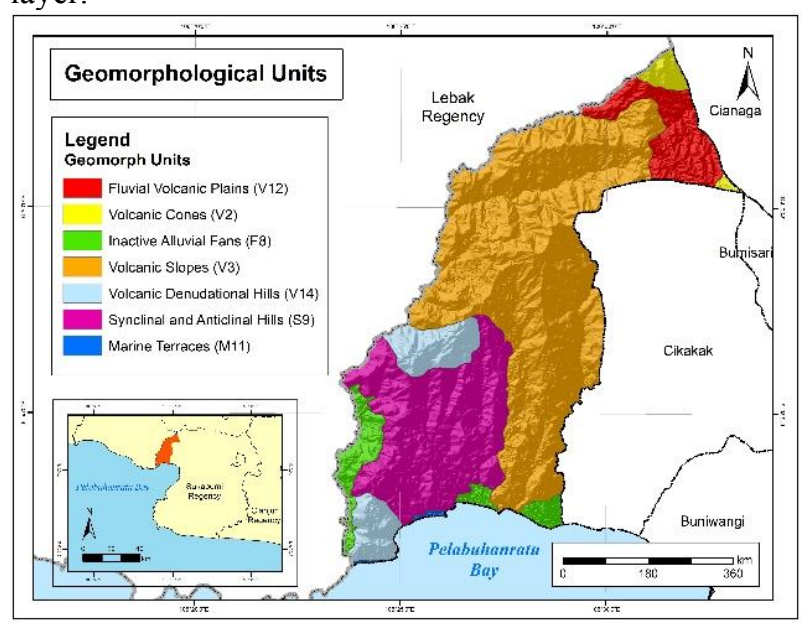

Fig. 2. Geomorphological Units in Study Area

\subsection{Landslide-Prone Area (LPA)}

\subsubsection{Landslide Inventory Map}

Tropical regions like Indonesia have dense vegetation cover, so the landslide locations must be carried out through field surveys. The interpretation of Google Earth's image also applied to help identified landslide locations which difficult to reach.

Forty-two locations of landslides mapped with a total area of 13 hectares. The majority of landslides were identified to rotational (north side) and fall (south side) type. According to information from BPBD officer, all landslides triggered by steep slopes and unstable land. Rainfall does not affect too much because landslides also occurred in dry season.

\subsubsection{Landslide Causative Factors}

The causative factors determined from previous research, local residents, and study literature. Those factors are shown in table 4 . The frequency ratio for slopes shows that the slope of $30-140 \%$ has the highest frequency ratio value. The slope $70-140 \%$ is the highest class with a weight 1.58 followed by a slope $30-70 \%$ with a weight 1.12. Lithological aspect has significant influence, tapos breccia formation is the most giant rock formation becomes the most suitable landslide-prone with the highest weight 1.82 .

Each distance from the road in each class has high value, mostly have more than one but the highest weight 
in range area 201-250 $\mathrm{m}$ with 2.36 . The ranging area 101$250 \mathrm{~m}$ for stream also has significant influence, highest weight 2.27 found in 151-200 $\mathrm{m}$ range area followed by range area 201-250 m with 2.23 and range area 101-150 $\mathrm{m}$ with 1.72 . The fault line only has two values in class, there is buffer $<50 \mathrm{~m}$ with weight 0.85 and buffer $>250$ $m$ with weight 1.06 .

While in land use, crop fields have very high values reach 5.78. As predicted, forest and beach have no weight, but barren land unexpectedly also has no weight. From five soil types in the study area, the andosol district is the highest weight 1.3. Rainfall does not have much effect on landslides, the study area has homogeneous rainfall 2.500-3.000 $\mathrm{mm}$ with a value of 1 .

Table 4. Frequency Ratio Values

\begin{tabular}{|c|c|c|c|c|c|c|}
\hline Factors & Classes & $\mathbf{N i j}$ & $\begin{array}{l}\mathrm{Nij} / \mathbf{N} \\
\mathbf{r}(\%)\end{array}$ & $\mathbf{A} \mathbf{i j}$ & $\begin{array}{l}\mathbf{A i j} / \mathbf{A} \\
\mathbf{r}(\%)\end{array}$ & FR \\
\hline \multirow{7}{*}{ Slope (\%) } & $<2$ & 8764 & 0.35 & 0 & 0 & 0 \\
\hline & 02-Jul & 88863 & 3.55 & 4 & 2.52 & $\begin{array}{c}0.7 \\
1\end{array}$ \\
\hline & Jul-15 & 322622 & 12.89 & 19 & 11.95 & $\begin{array}{c}0.9 \\
3\end{array}$ \\
\hline & $15-30$ & 857967 & 34.27 & 48 & 30.19 & $\begin{array}{c}0.8 \\
8\end{array}$ \\
\hline & $30-70$ & 1185530 & 47.35 & 84 & 52.83 & $\begin{array}{c}1.1 \\
2\end{array}$ \\
\hline & $70-140$ & 39742 & 1.59 & 4 & 2.52 & $\begin{array}{c}1.5 \\
8\end{array}$ \\
\hline & $>140$ & 54 & 0 & 0 & 0 & 0 \\
\hline \multicolumn{2}{|c|}{ Total } & 2503542 & 100 & 159 & 100 & $\begin{array}{c}5.2 \\
2 \\
\end{array}$ \\
\hline \multirow{14}{*}{ Lithology } & QA & 371 & 1.18 & 0 & 0 & 0 \\
\hline & QB & 154 & 0.49 & 0 & 0 & 0 \\
\hline & QPV & 764 & 2.42 & 0 & 0 & 0 \\
\hline & QVB & 15942 & 50.53 & 146 & 91.82 & $\begin{array}{c}1.8 \\
2\end{array}$ \\
\hline & QVL & 4441 & 14.08 & 0 & 0 & 0 \\
\hline & TEMV & 1306 & 4.14 & 8 & 5.03 & $\begin{array}{c}1.2 \\
2\end{array}$ \\
\hline & TMA & 484 & 1.53 & 0 & 0 & 0 \\
\hline & TMC & 566 & 1.79 & 1 & 0.63 & $\begin{array}{c}0.3 \\
5\end{array}$ \\
\hline & TMCL & 315 & 1 & 0 & 0 & 0 \\
\hline & TMD & 74 & 0.23 & 0 & 0 & 0 \\
\hline & TMDA & 2094 & 6.64 & 0 & 0 & 0 \\
\hline & TMT & 1207 & 3.83 & 0 & 0 & 0 \\
\hline & TMTL & 194 & 0.61 & 0 & 0 & 0 \\
\hline & TPV & 3635 & 11.52 & 4 & 2.52 & $\begin{array}{c}0.2 \\
2 \\
\end{array}$ \\
\hline \multicolumn{2}{|c|}{ Total } & 31547 & 100 & 159 & 100 & 3.6 \\
\hline \multirow{5}{*}{$\begin{array}{c}\text { Distance } \\
\text { To Road } \\
\text { (m) }\end{array}$} & $<50$ & 4330 & 13.3 & 31 & 19.5 & $\begin{array}{c}1.4 \\
7\end{array}$ \\
\hline & $51-100$ & 3568 & 10.96 & 32 & 20.13 & $\begin{array}{c}1.8 \\
4\end{array}$ \\
\hline & $101-150$ & 2859 & 8.78 & 24 & 15.09 & $\begin{array}{c}1.7 \\
2 \\
\end{array}$ \\
\hline & $151-200$ & 2389 & 7.34 & 15 & 9.43 & $\begin{array}{c}1.2 \\
9\end{array}$ \\
\hline & $201-250$ & 1999 & 6.14 & 23 & 14.47 & $\begin{array}{c}2.3 \\
6\end{array}$ \\
\hline
\end{tabular}

\begin{tabular}{|c|c|c|c|c|c|c|}
\hline & $>250$ & 17401 & 53.47 & 34 & 21.38 & 0.4 \\
\hline \multicolumn{2}{|c|}{ Total } & 32546 & 100 & 159 & 100 & $\begin{array}{c}9.0 \\
6\end{array}$ \\
\hline \multirow{6}{*}{$\begin{array}{c}\text { Distance } \\
\text { To River } \\
\quad(\mathrm{m})\end{array}$} & $<50$ & 12570 & 38.62 & 27 & 16.98 & $\begin{array}{c}0.4 \\
4\end{array}$ \\
\hline & $51-100$ & 9628 & 29.58 & 42 & 26.42 & $\begin{array}{c}0.8 \\
9\end{array}$ \\
\hline & $101-150$ & 5480 & 16.84 & 46 & 28.93 & $\begin{array}{c}1.7 \\
2\end{array}$ \\
\hline & $151-200$ & 2611 & 8.02 & 29 & 18.24 & $\begin{array}{c}2.2 \\
7\end{array}$ \\
\hline & $201-250$ & 1103 & 3.39 & 12 & 7.55 & $\begin{array}{c}2.2 \\
3\end{array}$ \\
\hline & $>250$ & 1154 & 3.55 & 3 & 1.89 & $\begin{array}{c}0.5 \\
3\end{array}$ \\
\hline \multicolumn{2}{|c|}{ Total } & 32546 & 100 & 159 & 100 & $\begin{array}{c}8.0 \\
8\end{array}$ \\
\hline \multirow{6}{*}{$\begin{array}{c}\text { Distance } \\
\text { To Road } \\
\text { (m) }\end{array}$} & $<50$ & 481 & 1.48 & 2 & 1.26 & $\begin{array}{c}0.8 \\
5\end{array}$ \\
\hline & $51-100$ & 412 & 1.27 & 0 & 0 & 0 \\
\hline & $101-150$ & 469 & 1.44 & 0 & 0 & 0 \\
\hline & $151-200$ & 491 & 1.51 & 0 & 0 & 0 \\
\hline & $201-250$ & 404 & 1.24 & 0 & 0 & 0 \\
\hline & $>250$ & 30289 & 93.07 & 157 & 98.74 & $\begin{array}{c}1.0 \\
6\end{array}$ \\
\hline \multicolumn{2}{|c|}{ Total } & 32546 & 100 & 159 & 100 & $\begin{array}{c}1.9 \\
1\end{array}$ \\
\hline \multirow{9}{*}{ Landuse } & Rice fields & 6842 & 21.6 & 19 & 12.34 & $\begin{array}{c}0.5 \\
7\end{array}$ \\
\hline & $\begin{array}{c}\text { Build up } \\
\text { area }\end{array}$ & 968 & 3.06 & 6 & 3.9 & $\begin{array}{c}1.2 \\
8 \\
\end{array}$ \\
\hline & Crop fileds & 3665 & 11.57 & 103 & 66.88 & $\begin{array}{c}5.7 \\
8\end{array}$ \\
\hline & $\begin{array}{l}\text { Agricultura } \\
1 \text { fields } \\
\end{array}$ & 5505 & 17.38 & 2 & 1.3 & $\begin{array}{c}0.0 \\
7\end{array}$ \\
\hline & Water body & 117 & 0.37 & 0 & 0 & 0 \\
\hline & Shrubs & 4013 & 12.67 & 23 & 14.94 & $\begin{array}{c}1.1 \\
8\end{array}$ \\
\hline & Forest & 10498 & 33.14 & 1 & 0.65 & $\begin{array}{c}0.0 \\
2\end{array}$ \\
\hline & Barren land & 53 & 0.17 & 0 & 0 & 0 \\
\hline & Beach & 21 & 0.07 & 0 & 0 & 0 \\
\hline \multicolumn{2}{|c|}{ Total } & 31682 & 100 & 154 & 100 & \\
\hline \multirow{5}{*}{ Soil Type } & $\begin{array}{c}\text { Aluvial } \\
\text { sulfic }\end{array}$ & 219 & 0.67 & 0 & 0 & 0 \\
\hline & $\begin{array}{c}\text { Andosol } \\
\text { district }\end{array}$ & 22729 & 69.79 & 141 & 90.38 & 1.3 \\
\hline & $\begin{array}{c}\text { Kambisol } \\
\text { district }\end{array}$ & 5248 & 16.11 & 13 & 8.33 & $\begin{array}{c}0.5 \\
2 \\
\end{array}$ \\
\hline & $\begin{array}{c}\text { Kambisol } \\
\text { eutric }\end{array}$ & 4332 & 13.3 & 2 & 1.28 & 0.1 \\
\hline & $\begin{array}{c}\text { Podsolik } \\
\text { haplic }\end{array}$ & 40 & 0.12 & 0 & 0 & 0 \\
\hline \multicolumn{2}{|c|}{ Total } & 32568 & 100 & 156 & 100 & $\begin{array}{c}1.9 \\
1\end{array}$ \\
\hline \multirow{6}{*}{$\begin{array}{l}\text { Rainfall } \\
\text { (mm/year) }\end{array}$} & $<1500$ & 0 & 0 & 0 & 0 & 0 \\
\hline & $1501-2000$ & 0 & 0 & 0 & 0 & 0 \\
\hline & $2001-2500$ & 0 & 0 & 0 & 0 & 0 \\
\hline & $2501-3000$ & 31619 & 100 & 159 & 100 & 1 \\
\hline & $3001-3500$ & 0 & 0 & 0 & 0 & 0 \\
\hline & $>3500$ & 0 & 0 & 0 & 0 & 0 \\
\hline \multicolumn{2}{|c|}{ Total } & 31619 & 100 & 159 & 100 & 1 \\
\hline
\end{tabular}




\subsubsection{Landslide-Prone Area}

Selected causative factors that have Frequency Ratio value combined using the overlay technique to obtain landslide-prone area map. The result of the combination produces a range of values 2.01-17.17. Which divided into four classes of vulnerability there are low, moderate, high, and very high.

Table 5. Level of Vulnerability

\begin{tabular}{|c|c|c|c|}
\hline Vulnerability & $\begin{array}{c}\text { LVI } \\
\text { Values }\end{array}$ & Area $\left(\mathbf{k m}^{\mathbf{2}}\right)$ & $\begin{array}{c}\text { Percentage } \\
\mathbf{( \% )}\end{array}$ \\
\hline Low & $2.01-5.79$ & 29.39 & 17.03 \\
\hline Moderate & $5.80-9.58$ & 107.06 & 62.05 \\
\hline High & $9.59-13.37$ & 24.85 & 14.40 \\
\hline Very High & $13.38-17.17$ & 11.24 & 6.51 \\
\hline \multicolumn{2}{|c|}{ Total } & 173.49 & 100.00 \\
\hline
\end{tabular}

The result shows that the low class covers $17.03 \%$ and moderate class covers $62.05 \%$ of the total area. While the high class covers $14.4 \%$ and specifically very high class covers $6.51 \%$ of the total area. Distribution of high and very high class separated in west and east.

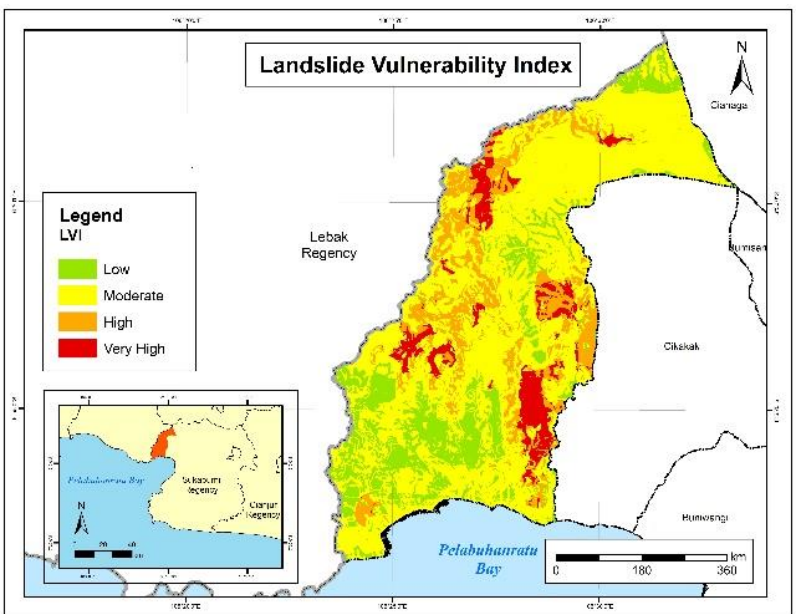

Fig. 3. Landslide Vulnerability Index

Landslide prone areas indicate the possibility of landslides in study area, it can be influenced by landform and geomorphic process. High to very high prone areas are located in volcanic slopes, separated in west and east. Volcanic slopes dominated by $30-70 \%$ slope angel and formed by volcanic loose igneous rocks that consist of lava, breccia, tuff, and agglomerates. Volcanic materials such as volcanic ash constructed a thick layer of soil which susceptible to erosion. Massive wheatering of bedrocks also occurred in this area, so it makes the surface very unstable. Fragile materials easily falling down on steep slope in the hilly area as a slip plane.

Then, the low and moderate prone areas found in synclinal and anticlinal hills, marine terraces, inactive alluvial fans, fluvial volcanic plains, and volcanic cones. Few geomorphic processes like erosion and weathering found in this area, it can indicate that the land could be more compact and not vulnerable to landslides.

\section{Conclusion}

Generally, the study area has flat to mountainous terrain dominated by a steep hill. Flat area constructed by the fluvial and marine process, while hilly to mountainous areas constructed by the volcanic and structural process. Seven categories of geomorphological units obtained, dominated by volcanic slopes. Frequency ratio (FR) method applied to identified landslide-prone area by combine landslide inventory map and causative factor. Field survey is conducted to obtain a landslide inventory map and selected causative factors determined based on physical conditions that affect landslides. The result shows that high to very high class covers $20,91 \%$ of total area separated in west and east. High to very high prone located in volcanic slopes, influenced by massive erosion and weathering process overtime.

Thanks to Directorate of Research and Community Service (DRPM) Universitas Indonesia that has supported this research in the form of Hibah PITTA.

\section{References}

1. P.D. Susanti, A. Miardini, B. Harjadi, J. of Watershed Manag. Res., 1, 49-59 (2017)

2. N.I. Ramadhani, \& H. Idajati, Jurnal Teknik ITS., 6, 2337-3539 (2017)

3. Badan Nasional Penanggulangan Bencana (BNPB), Disaster Statistics, https://bnpb,cloud/dibi/tabel1b (2019)

4. Badan Penanggulangan Bencana Daerah (BPBD) Kabupaten Sukabumi, Data Bencana Kabupaten Sukabumi tahun 2011-2018, (2019).

5. Peraturan Presiden No.28 Tahun 2012 tentang RTR Jawa-Bali

6. J.B. Nsengiyumva, G. Luo, L. Nahayo, X. Huang, P. Cai, Int. J. Environ. Res. And Pub. Health, 15, $1457-$ 1472 (2018)

7. Van Zuidam, R. A. (1985). Aerial Photointerpretation in Terrain Analysis and Geomorphologic Mapping. The Hague, The Netherlands: Smits.

8. Basu. T, Pal. S, Adv. in Space Res, Elsevier, 63, 1253-1269 (2019)

9. K.D. Priyono, Priyono, Indo. J. of Spatial and Reg. Analysis, Forum Geografi, 22, 72-84 (2008)

10. A. Aditian, Kubota. T, Shinohara. Y, Geomorph., Science Direct, 318, 101-111 (2018)

11. Agricultural Reseacrh and Development Agency (BBSDLP), National Soil Classification (2016)

12. S. Lee, J. Abdul Thalib, Environ. Geol., 47, 982-990 (2005) 
13. Y. He, R.E. Beighley, Earth Surf. Process. Landf., 33, 380-393 (2008)

14. B. Pradhan, S. Lee, Environ. Earth. Scie, 60, 10371054 (2009)

15. S. Lee, B. Pradhan, Landslides, Springer-Verlag, 4, 33-41 (2007)

16. H. Khan, M. Shafique, M. A. Khan, The Egyptian J. of RS and Space Sci., Science Direct, 22, 11-24 (2019) 